Annals of Warsaw University of Life Sciences - SGGW

Horticulture and Landscape Architecture No 41, 2020: 17-27

(Ann. Warsaw Univ. of Life Sci. - SGGW, Horticult. Landsc. Architect. 41, 2020)

DOI 10.22630/AHLA.2020.41.2

\title{
Selection for resistance to acequinocyl in Amblyseius andersoni (Chant) (Anactinotrichida: Phytoseiidae)
}

\author{
EWA PUCHALSKA
}

Institute of Horticultural Sciences, Warsaw University of Life Sciences - SGGW

\begin{abstract}
Selection for resistance to acequinocyl in Amblyseius andersoni (Chant) (Anactinotrichi$d a$ : Phytoseiidae). The majority of pesticides used in pest control in orchards are found to be harmful to beneficial arthropods. However, the development of resistant predators and parasitoids could contribute to their enhanced use in crops where the use of pesticides is necessary. The goal of the current work was to select a line of predatory mite Amblyseius andersoni resistant to acequinocyl acaricide belonging to a group of mitochondrial complex III electron transport inhibitors. A selective dose used in experiments was that causing $55-65 \%$ mortality of phytoseiid gravid females. A laboratory population had a nine-fold increase in resistance to acequinocyl after two selection cycles, and over 30 -fold increase after four cycles. This selected population of $A$. andersoni also developed medium cross-resistance to fenpyroximate.
\end{abstract}

Key words: predatory mites, pesticides, selection, acequinocyl, fenpyroximate

\section{INTRODUCTION}

Integration of a biocontrol agent (BCA) into most agricultural systems will not be successful unless the natural enemy can survive chemical treatments in these crops (Zalom and Irigaray 2010). Thus, studies on the side-effect of pesticides on beneficial organisms as well as attempts of the selection of natural enemies resistant to synthetic insecticides and acaricides are essential for effective integrat- ed pest management (IPM). Among the beneficial arthropods, phytoseiid mites play an important role as predators of many herbivores, especially spider mites (McMurtry and Croft 1997, Nomikou et al. 2001). While spider mites develop resistance to a number of pesticides within a short period of time, predacious mites react not so promptly (Overmeer and van Zon 1981, Hull and Beers 1985). Enhancing the phytoseiid survival after pesticides application may result in more effective control of phytophagous insects and mites (Fournier et al. 1985, Solomon et al. 1993).

Amblyseius andersoni (Chant) is a phytoseiid species commonly found on apple and peach trees in many European countries (Koveos and Broufas 2000, Stojnić et al. 2014). It was reported as an important predator of orchards' key pests, i.e. the European red spider mite (Panonychus ulmi (Koch)) and two-spotted spider mite (Tetranychus urticae Koch) (Ivancich-Gambaro 1986, Mc-Murtry and Croft 1997, Fiedler 2009, Szabo and Penzes 2013). The resistance of $A$. andersoni to various pesticides was previously confirmed in laboratory and field investigations. Ioriatti et al. (1992) reported the $A$. andersoni strain from San Michele all'Adige (Italy) resistant to dithianon. Females of the Italian strain 
treated with another fungicide - mancozeb - also survived, but showed significantly reduced fecundity. Whilst Duso (1992) observed a high sensitivity of $A$. andersoni to the pyrethroids used in Italian orchards, Bonafos et al. (2007) have found strains of this predator resistant to deltamethrin and lambda-cyhalothrin in the vineyards of south-western France. Another A. andersoni strain from France was resistant to organophosphates, namely chlorpyriphos-ethyl (Bonafos et al. 2007). It was previously proved that, in $A$. andersoni, at least two genes responsible for pesticide resistance are operating, one causing the formation of highly insensitive acetyl cholinesterase and one encoding for an enzyme able to hydrolyse various organophosphates (Anber and Overmeer 1988, Anber and Oppenoorth 1989). Still, we do not know much about the resistance potential of $A$. andersoni to mitochondrial electron transport inhibitors (METI) (James 2002, Rodrigues and Torres 2007), an important group of acaricides. One of them - acequinocyl - is an active substance of the naphtoquinones class. Its mode of action is to inhibit electron transfer in the mitochondria of spider mites via inhibition of the $\mathrm{Q}_{0}$ centre by acting as a structural analogue of ubiquinone (Kinoshita et al. 1999). Acequinocyl has been designated as a "reducedrisk" pesticide with low pest resistance potential and lower toxicity to non-target organisms (Tiwari 2013). However its impact on $A$. andersoni has not been studied so far. The present study was set up to assess the resistance potential of commercially available $A$. andersoni to acequinocyl (mitochondrial complex III electron transport inhibitor) and the cross-resistance of the A. andersoni population produced via selection pressure in the laboratory to another acaricide, fenpyroximate (mitochondrial complex I electron transport inhibitor).

\section{MATERIAL AND METHODS}

\section{Stock colony of Amblyseius andersoni}

The stock colony of $A$. andersoni was initiated with specimens (Anderline Pro Bioline AgroSciences Ltd., United Kingdom) obtained from Hortico SA Company (Wrocław, Poland). The colony was then maintained in the laboratory of the Section of Applied Entomology (Warsaw University of Life Sciences - SGGW) in an environmental test chamber $(25$ $\pm 0.5^{\circ} \mathrm{C}, 70 \pm 10 \% \mathrm{RH}, 16 \mathrm{~L}: 8 \mathrm{D}$ photoperiod). Using a fine paintbrush, the predators were placed in breeding containers $(18 \times 15 \times 7 \mathrm{~cm})$. In each container a tile of black plastic $(15 \times 1 \mathrm{~cm})$ was resting on a sponge $(16 \times 13 \times 4.5 \mathrm{~cm})$ dipped in water. Wet tissue paper strips $(1 \mathrm{~cm}$ wide) formed a barrier around the tile. On the tissue paper a ring of insect glue (fruit tree grease Vitax ${ }^{\circledR}$ ) was laid as a barrier to prevent predators escape. Several roof-shaped pieces of transparent plastic with black sewing threads underneath were placed on the tile as shelters where the phytoseiids could deposit their eggs. Amblyseius andersoni was fed with cattail pollen (Nutrimite ${ }^{\circledR}$ ) and reared in these conditions for at least four generations before the start of the experiment.

\section{Acaricides and bioassay unit}

Two commercial METI acaricides were used: Kanemite ${ }^{\circledR} 150 \mathrm{SC}$ with acequinocyl as an active ingredient (14.42\%; 
$\left.150 \mathrm{~g} \cdot \mathrm{L}^{-1}\right) \quad$ (Cheminova Deutschland $\mathrm{GmbH} \&$ Co. KG, Germany) and Otrus ${ }^{\circledR 05} \mathrm{SC}$ with fenpyroxymate $\left(5.02 \% ; 51.2 \mathrm{~g} \cdot \mathrm{L}^{-1}\right)$ (Nichino Europe Co., United Kingdom). Each bioassay unit consisted of a detached been leaf placed upside-down on a Plexiglas plate $(10 \times 5 \times 0.3 \mathrm{~cm})$ covered with four-times folded wet filter paper. The four-centimetre diameter ring of sticky barrier $\left(\operatorname{Vitax}{ }^{\circledR}\right)$ was provided on each leaf, to prevent the predators from escaping.

\section{Toxicity tests}

The method of Sato et al. (2000) was modified for selection studies. Four days before the test a mass of $A$. andersoni deutonymphs was transferred to a separate breeding container (prepared as described previously). After two days, males were added to the container for $24 \mathrm{~h}$, to provide mating opportunities to the newly emerged females. Only gravid females were then chosen for the experiments. Ten $A$. andersoni females were transferred on each bean leaf arena before planned sprayings. At least 400 females were used in each selection. As according to Irigaray and Zalom (2006), pesticides mixed with distilled water were applied using a 200-millilitre hand sprayer held $30 \mathrm{~cm}$ away from the leaf surface. The untreated controls were sprayed with distilled water alone. Females were left on the bean leaves for three days after spraying, incubated in the environmental test chamber $\left(25 \pm 0.5^{\circ} \mathrm{C}, 70 \pm 10 \% \mathrm{RH}\right.$, $16 \mathrm{~L}: 8 \mathrm{D})$. The next day after spraying, cattail pollen was provided into arenas as food for survivors. Individual mite survival was determined $72 \mathrm{~h}$ after treatment by light touching each specimen with a fine brush. Phytoseiids unable to react were considered dead.

The maximum concentration of tested acaricides was used, corresponding to those suggested by producers for field application: $561 \mathrm{mg}$ ai $\cdot \mathrm{L}^{-1}$ for acequinocyl (recommendations from 2014-2015, nowadays $295-280 \quad \mathrm{mg} \mathrm{ai} \cdot \mathrm{L}^{-1}$ ) and $128 \mathrm{mg} \mathrm{ai} \cdot \mathrm{L}^{-1}$ for fenpyroximate. To determine $\mathrm{LC}_{50}$ values of the selected and initial populations of $A$. andersoni a blank control and seven acequinocyl or three fenpyroximate doses were prepared with a one-half serial dilution series.

\section{Selection for resistance}

According to Sato et al. (2000), a selective pesticide concentration (initiating selective pressure towards predator's resistance to tested pesticide) is that causing mortality from 55 to $65 \%$ of treated individuals. Therefore, $72 \mathrm{~h}$ after each spraying, females from the combination in which $35-45 \%$ of treated individuals survived were transferred to a new breeding container (prepared as described previously). Females and their progeny were rearing in the container kept in the environmental test chamber $\left(25 \pm 0.5^{\circ} \mathrm{C}\right.$, $70 \pm 10 \%$ RH, 16L : 8D) and fed with cattail pollen. The second selection spraying was after 7-9 days, which corresponded to the period required for reaching maturity of the progeny (F1) of selected females. The spraying procedure was similar to that described in the "Toxicity tests" section. As there was a decrease in female fecundity in the F1 generation, further spraying intervals were adopted from 21 to 27 days. This period, corresponding to the required time for approximately three generations, allowed 
a sufficient number of individuals (in F4, F7, F10) to be tested.

\section{Cross-resistance tests}

To determine the effect of cross-resistance of the selected $A$. andersoni population to fenpyroximate, females in the acequinocyl selected F11 generation as well as those in the initial population were sprayed with three concentrations of this acaricide (procedure described in the "Toxicity tests" section).

\section{Data analyses}

The concentration-response data were subjected to probit analysis (LeOra Software 1994). The response of each generation was considered different if the $95 \%$ confidence limits at the $\mathrm{LC}_{50}$ did not overlap. The survival values of females were corrected by Abbott's formula (1925). The Mann-Whitney test for comparing the survival of females in the initial and selected populations was used. The significance level for all analyses was 0.05 . Statistical elaboration was performed in the statistical software package PAST version 2.02 (Hammer et al. 2010). Percentage data were arcsine transformed for ANOVA. Resistance ratios (RR) were obtained by dividing the $\mathrm{LC}_{50}$ values of the selected populations by the $\mathrm{LC}_{50}$ value of the initial population.

\section{RESULTS AND DISCUSSION}

Integration pesticides and the biocontrol of mites in agricultural systems should comprise practices such as: use the least disruptive pesticides for pest control, monitoring for spider mites, monitoring for predators (including phytoseiids), use of economic thresholds, considering predator-prey ratios before applying pesticides and employing releases of pesticide-resistant predators when augmentation is needed (Hoy et al. 1982, Zalom and Irigaray 2010). In augmentative biological control, naturally or artificially selected natural enemies that are resistant to pesticides can be used. In the current work, the initial (commercially available) population of $A$. andersoni was exposed to four selection cycles to determine the development of acequinocyl resistance. The subsequent steps of this process resulting in mortality changes of tested females are shown in Figure 1. These data were used to estimate the $\mathrm{LC}_{50}$ values of each generation (the table). In the initial population, the lethal acequinocyl concentration causing a $50 \%$ mortality of the tested $A$. andersoni females was $8.78 \mathrm{mg} \cdot \mathrm{L}^{-1}$. In the selected $\mathrm{F} 1$ generation, the $\mathrm{LC}_{50}$ value increased to $25.34 \mathrm{mg}$ ai $\cdot \mathrm{L}^{-1}$ showing a threefold increase of resistance to acequinocyl compared to the initial population. After four selections for resistance, the $\mathrm{LC}_{50}$ value increased from 8.79 to $267.07 \mathrm{mg} \mathrm{ai} \cdot \mathrm{L}^{-1}$, and the resistance ratio increased by 30.4-fold (the table). The selected $A$. andersoni strain with the 30.4-fold increase of resistance to acequinocyl was named the AAP4 population. Salman et al. (2015) have shown a similar increase (32.75-fold) in resistance developed with six-time continuous selection with acequinocyl in another phytoseiid mite population - Phytoseiulus persimilis Athias-Henriot. Our selection was not conducted continuously, still, a significant increase in resistance was obtained. This is consistent with 

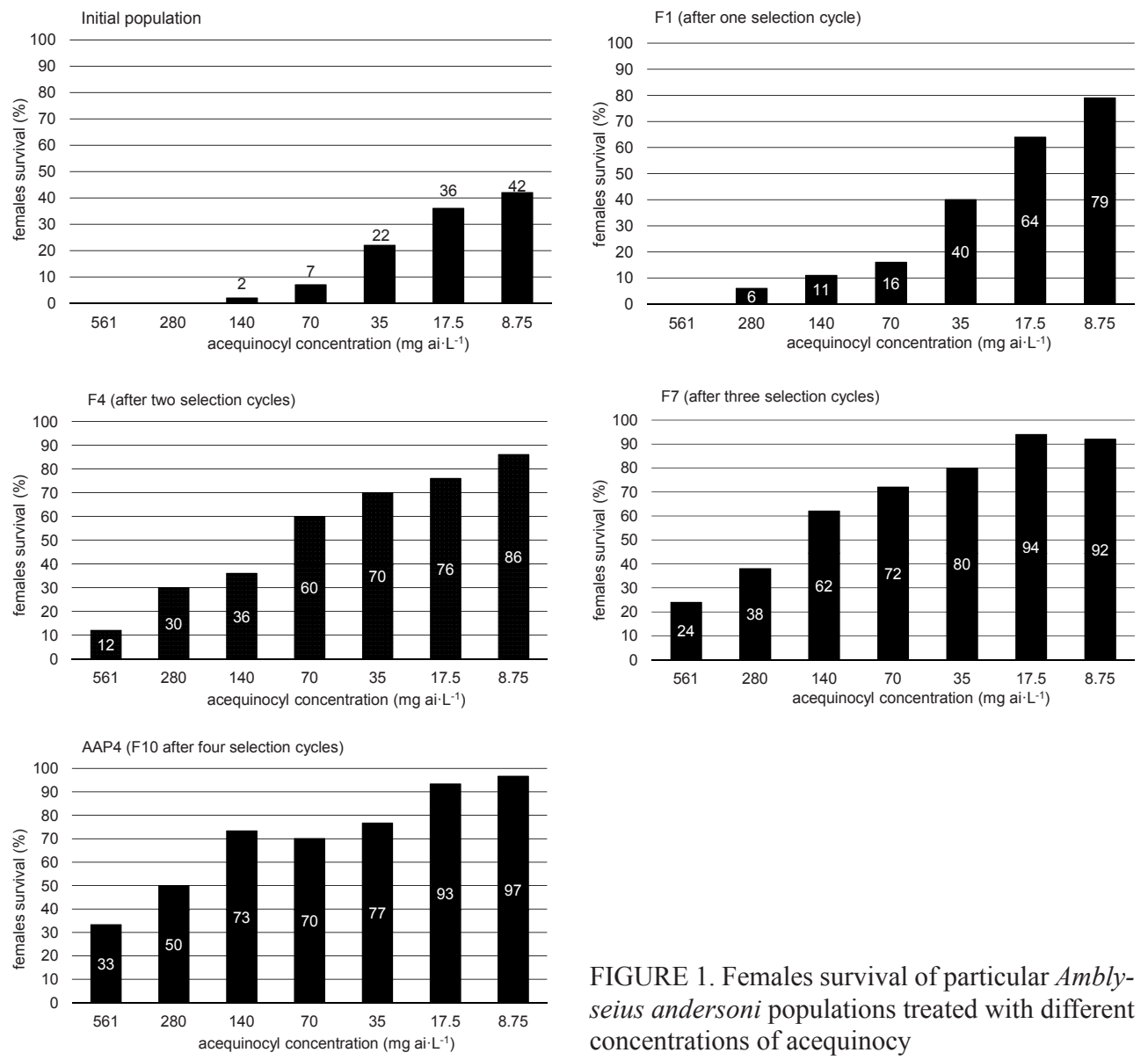

the findings of other authors who reported that the selections for pesticide resistance in Phytoseiidae might be efficient despite the fact that the intervals between selections are longer than one generation (Sato et al. 2000). The laboratory selection for resistance changed the susceptibility of $A$. andersoni to acequinocyl. The survival of females in the initial population and the selected AAP4 population treated with different concentrations of acequinocyl is shown in Figure 2. The significance of differences in survival of $A$. andersoni females of both

FIGURE 1. Females survival of particular Amblyseius andersoni populations treated with different concentrations of acequinocy

populations was compared in combination with 8.75 to $140 \mathrm{mg}$ ai $\cdot \mathrm{L}^{-1}$ because no female in the initial population survived treatments with the pesticide in the concentration $561 \mathrm{mg}$ ai $\cdot \mathrm{L}^{-1}$ (a dose recommended for orchard sprayings in 2014-2015) and $280 \mathrm{mg}$ ai $\cdot \mathrm{L}^{-1}$ (currently recommended). Thus it can be stated that the initial population of $A$. anderosni was highly susceptible to acequinocyl. In comparison, $33 \%$ of females of the selected AAP4 population survived spraying with the highest concentration of acequinocyl and $50 \%$ the treatment with half 
TABLE. Resistance ratio and $\mathrm{LC}_{50}$ levels determined after selection with acequinocyl from Amblyseius andersoni populations

\begin{tabular}{|l|c|c|c|c|c|c|}
\hline \multirow{2}{*}{ Treatment } & Formulation & Population & $n$ & $\begin{array}{c}\text { Slope } \pm S E \\
(0.95 \% \mathrm{CL})\end{array}$ & $\begin{array}{c}\mathrm{LC}_{50}\left(\mathrm{mg} \mathrm{ai} \cdot \mathrm{L}^{-1}\right) \\
(0.95 \% \mathrm{CL})\end{array}$ & $R R^{*}$ \\
\hline \multirow{4}{*}{ Acequinocyl } & \multirow{3}{*}{$\begin{array}{c}\text { Kanemite } \\
\text { 150SC }\end{array}$} & initial population & 1200 & $1.61 \pm 0.35$ & 8.78 & - \\
\cline { 3 - 7 } & & select-1 (F1) & 800 & $1.64 \pm 0.38$ & 25.34 & 2.88 \\
\cline { 3 - 7 } & & select-2 (F4) & 800 & $1.20 \pm 0.30$ & 80.45 & 9.16 \\
\cline { 3 - 7 } & & select-3 (F7) & 400 & $1.25 \pm 0.32$ & 183.43 & 20.89 \\
\cline { 3 - 7 } & & AAP4 (F10) & 400 & $1.17 \pm 0.30$ & 267.06 & 30.41 \\
\hline \multirow{2}{*}{ Fenpyroximate } & \multirow{2}{*}{ Ortus 05SC } & initial population & 400 & $0.93 \pm 0.2$ & 3.35 & - \\
\cline { 3 - 7 } & & AAP4 & 400 & $1.46 \pm 0.34$ & 40.32 & 12.03 \\
\hline
\end{tabular}

$*$ Resistance ratio $=$ the $\mathrm{LC}_{50}$ value of resistance population $/ \mathrm{LC}_{50}$ value of the susceptible population.

of that dose $\left(280 \mathrm{mg}\right.$ ai $\left.\cdot \mathrm{L}^{-1}\right)$. In the other combinations a significantly higher survival was observed in the selected population compared to the initial $(p<0.03)$. The biggest difference in females survival was noted when the concentration of $140 \mathrm{mg} \cdot \mathrm{L}^{-1}$ of aquinocyl was used. With this treatment only $2 \%$ of females in the initial population and $73 \%$ in the selected AAP4 strain survived (Fig. 2). There is scarce information about toxicity to phytoseiid mites pesticides that similarly to acequinocyl inhibit electron transport complex III preventing the utilization of energy by mites cells. One of these substances is bifenazate, which in the fullfield rate was moderately to highly toxic to $A$. andersoni and some other phytoseiids, i.e. Galendromus occidentalis Nesbitt and Neoseiulus fallacis Garman, causing $37-81 \%$ mortality of predators on hops grown in the US (James 2002). In contrast to bifenazate, acequinocyl seems to be a promising candidate for use in integrated mite management programs where $P$. persimilis or Amblyseius womersley Schicha are the major natural enemies. In laboratory surveys,
$88 \%$ of P. persimilis females and $86 \%$ of A. womersley survived spraying with acequinocyl at $150 \mathrm{mg} \cdot \mathrm{L}^{-1}$ (Kim and Seo 2001, Kim and Yoo 2002); however, the populations of phytoseiid mites tested by these authors originated from crops where various pesticides had been previously used, and so could be more resistant to acequinocyl than the $A$. andersoni population tested in the current study. Puchalska and Piotrowska (2016) demonstrated that acequinocyl was slightly or moderately toxic to Typhlodromus pyri Scheuten individuals that previously were in contact with pesticides and highly toxic to specimens that had never been under pesticide pressure.

The AAP4 A. andersoni population showed a medium-level development of cross-resistance to fenpyroximate (a 12.03-fold increase) - the table. Statistical analysis performed to compare the survival of $A$. andersoni females in the initial population and AAP4 population treated with the highest dose of fenpyroximate $\left(128 \mathrm{mg} \mathrm{ai} \cdot \mathrm{L}^{-1}\right)$ did not show significant differences $(p=0.0940)$ - Figure 3. However, spraying with half 


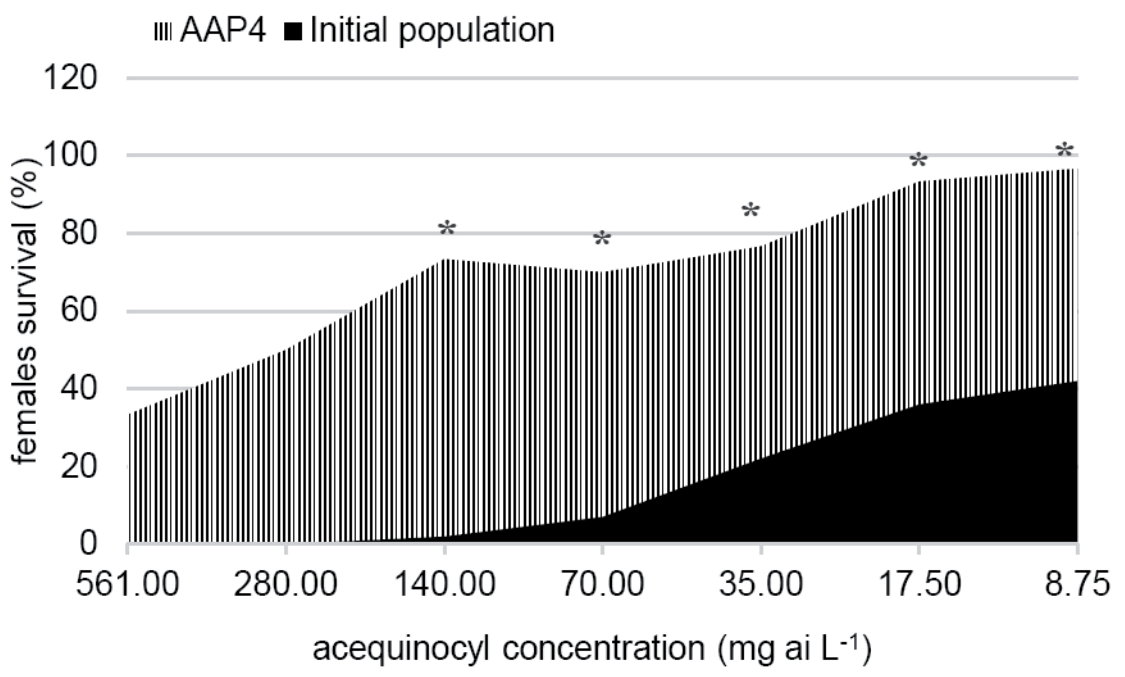

FIGURE 2. Survival of Amblyseius andersoni females in the initial population and laboratory selected AAP4 population treated with different concentrations of acequinocyl (an asterisk means a significant difference between populations; Mann-Whitney test; significance level 0.05)

of the dose $\left(64 \mathrm{mg}\right.$ ai $\left.\cdot \mathrm{L}^{-1}\right)$ nine times more females in the acequinocyl resistant population (AAP4) survived than in the initial one $(p=0.0007)$. Difference was also shown in both populations' survival when sprayed with $32 \mathrm{mg} \cdot \mathrm{L}^{-1}$ of fenpyroximate $(p=0.0261)$, with $14 \%$ of females in the initial population and $47 \%$ in the AAP4 population surviving (Fig. 3). The development of cross-resistance to fenpyroximate was observed despite the fact that fenpyroximate and acequinocyl bind to the mitochondrial system at different sites (complex I for fenpyroximate and complex III for acequinocyl) (Kinoshita et al. 1999). In field observations, the toxicity of fenpyroximate was assessed as slightly to moderately harmful to $A$. andersoni and Euseius stipulatus (Athias-Henriot) occurring in apple orchards in Portugal (Rodrigues and Torres 2007). It can be supposed that the acequinocyl and fen- pyroximate impact on the AAP4 strain of $A$. andersoni in field conditions will be less harmful than shown in these studies; laboratory results give higher mortality rates because of a higher exposure of females to pesticide under experimental bioassay than in field conditions where phytoseiids may disperse to untreated plant surfaces (Bonafos et al. 2007). Nevertheless, field trials verifying this hypothesis are needed.

\section{CONCLUSIONS}

Amblyseius andersoni is one of the most promising BCAs of spider mites occurring in European fruit crops (Caccia et al. 1985, Ivancich-Gambaro 1986, Croft et al. 1993, Fiedler 2009, Szabo and Penzes 2013), therefore the development of the predator strain resistant to acaricides commonly used in such crops 


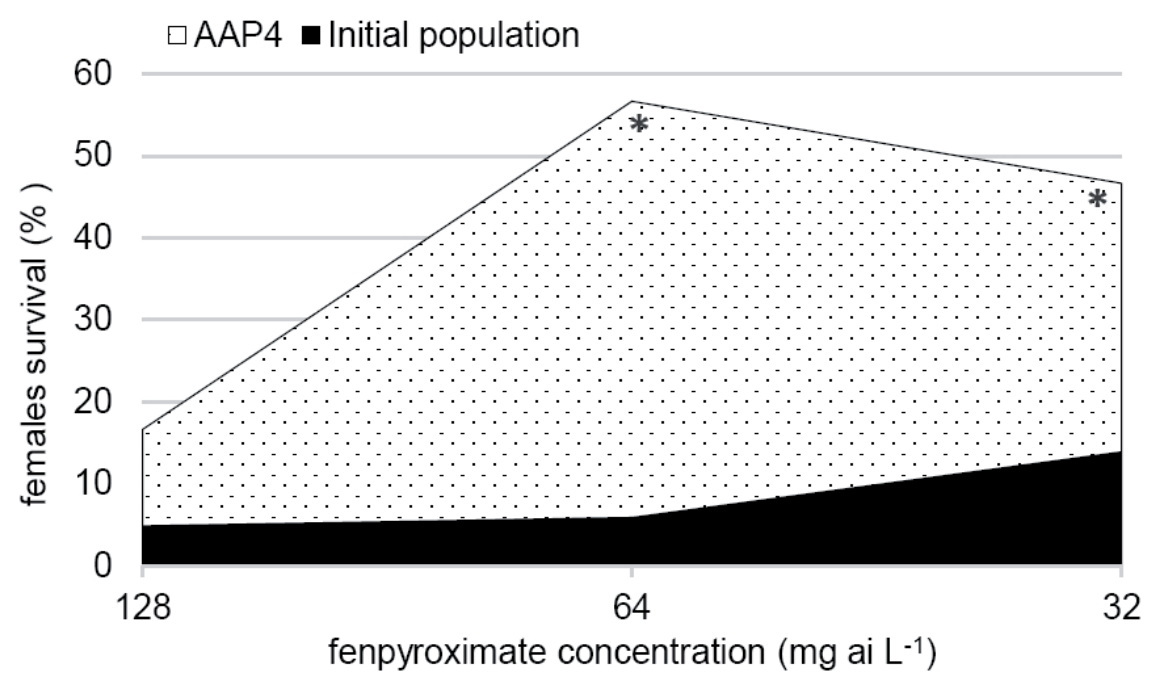

FIGURE 3. Survival of Amblyseius andersoni females in the initial population and laboratory selected AAP4 population treated with different concentrations of fenpyroximate (an asterisk means a significant difference between populations; Mann-Whitney test; significance level 0.05)

may increase its implementation in IPM systems. Current work has proved that A. andersoni specimens commercially available as Anderline Pro product, are highly susceptible to some METI type acaricides such as acequinocyl and fenpyroximate, which limits the chance of using these pesticides in crops where $A$. andersoni were introduced. The treating gravid females of the predator with a selective pesticide concentration causing mortality from 55 to $65 \%$ of the tested individuals seems to be an effective method of selecting an $A$. andersoni strain resistant to acequinocyl. The value of resistance rate increases with subsequent pesticide treatments. During four selection cycles lasting for 10 generations, it is possible to achieve an over 30 -fold increase in A. andersoni resistance to acequinocyl. It has been shown that the population selected for resistance to acequinocyl is more resistant than the initial (commercial) population to another pesticide, fenopyroximate. To assess the durability of resistance to acequinocyl in the selected AAP4 strain, further investigation providing the information whether the resistance is monogenic or polygenic and whether the resistance genes are dominant or recessive will be conducted.

\section{REFERENCES}

ABBOTT W. 1925: A method of computing the effectiveness of an insecticide. J. Econ. Entomol. 18: 265-267.

ANBER H.A.I., OVERMEER W.P.J. 1988: Resistance to organophosphates and carbamates in the predacious mite $\mathrm{Am}$ blyseius potentillae (Garman) due to insensitive acetylcholinesterase. Pestic. Biochem. Physiol. 31 (1): 91-98.

ANBER H.A.I, OPPENOORTH F.J. 1989: A mutant esterase degrading organophosphates in a resistant strain of the preda- 
cious mite Amblyseius potentillae (Garman). Pestic. Biochem. Physiol. 33 (3): 283-297.

BONAFOS R., SERRANO E., AUGER P., KREITER S. 2007: Resistance to delta-methrin, lambda-cyhalothrin and chlorpyriphos-ethyl in some populations of Typhlodromus pyri Scheuten and Ambylseius andersoni (Chant) (Acari: Phytoseiidae) from vineyards in the south-west of France. Crop Prot. 26: 169-172.

CACCIA R., BAILLOD M., GUIGNARD E., KREITER S. 1985: Introduction d'une souehe de Amblyseius andersoni Chant resistant a l'azinphos, dans la lutte contre les acariens phyto-phages en viticulture. Rev. Suisse Vitic. Arboric. Hortic. 17: 285-290.

CROFT B.A., MESSING R.H., DUNLEY J.E., STRONG W.B. 1993: Effects of humidity on eggs and immatures of NeOseiulus fallacis, Amblysieus andersoni, Metaseiulus occidentalis and Typhlodromus pyri (Phytoseiidae): implications for biological control on apple, caneberry, strawberry and hop. Exp. Appl. Acarol., 17: 451-459.

DUSO C. 1992: Biological control of tetranychid mites in peach orchards of Northern Italy: role of Amblyseius andersoni (Chant) and Amblyseius finlandicus (Oud.) (Acari: Phytoseiidae). Acta Phytopathol. Hun. 27: 211-217.

FIEDLER Ż. 2009: Amblyseius andersoni (Chant) - nowa alternatywa w zwalczaniu przędziorków [Amblyseius andersoni (Chant) - a new alternative in spider mites control]. Pro. Plant Prot. 49: 1469-1473.

FOURNIER D., PRALAVORIO M., BERGE J.B., CUANY A. 1985: Pesticide Resistance in Phytoseiidae. In: W. Helle, M.W. Sabelis (Eds.), Spider mites their biology, natural enemies and control 1B. Elsevier, Amsterdam.

HAMMER Q., HARPER D.A.T., RYAN P.D. 2010: PAST, version 2.02. State Univ. of NY at Stony Brook (Program).

HOY M.A., BARNETT W.W., REIL W.O., CASTRO D., CAHN D., HENDRICKS
L.C., COVIELLO R.L., BENTLEY W.J. 1982: Large-scale releases of pesticide-resistant spider mite predators. Calif. Agr. 36 (1): 8-10.

HULL LA. BEERS E.H. 1985: Ecological selectivity: Modifying Chemical Control Practices to Preserve Natural Enemies in Biological Control. In: M.A. Hoy, D.C. Herzog (Eds.), Agricultural IPM Systems. Academic Press, Orlando.

IORIATTI C., PASQUALINI E., TONIOLLI A. 1992: Effects of the fungicides mancozed and dithianon on mortality and reproduction of the predatory mite Amblyseius andersoni. Exp. Appl. Acarol. 15: 109-116.

IRIGARAY F.J.S.D.C., ZALOM F.G. 2006: Side effects of five new acaricides on the predator Galendromus occidentalis (Acari, Phytoseiidae). Exp. Appl. Acarol. 38: 299-305.

IVANCICH-GAMBARO P. 1986: An ecological study of Amblyseius andersoni Chant (Acarina: Phytoseiidae) in the climate of the Po Valley (North Italy). Long-term research on OP-resistant populations. Redia. 69: 555-572.

JAMES D.G. 2002: Selectivity of the acaricide, bifenazate, and aphicide, pymetrozine, to spider mite predators in Washington hops. Int. J. Acarol. 28: 175-179.

KIM S.S., SEO S.G. 2001: Relative toxicity of some acaricides to the predatory mite, Amblyseius womersleyi and the twospotted spider mite, Tetranychus urticae (Acari: Phytoseiidae, Tetranychidae). Appl. Entomol. Zool. 36: 509-514.

KIM S.S., YOO S.S. 2002: Comparative toxicity of some acaricides to the predatory mite, Phytoseiulus persimilis and the twospotted spider mite, Tetranychus urticae. BioControl 47: 563-573.

KINOSHITA S., KOURA Y., KARIYA H., OHSAKI N., WATANABE T. 1999: AKD-2023: a novel miticide. Biological activity and mode of action. J. Pestic. Sci. 55: 659-660.

KOVEOS D.S., BROUFAS G.D. 2000: Functional response of Euseius finlan- 
dicus and Amblyseius andersoni to Panonychus ulmi on apple and peach leaves in the laboratory. Exp. Appl. Acarol. 24: 247-256.

LeOra Software 1994: PoloPC: A Users guide to Probit and Logit Analysis. LeOra Software, Berkley, CA.

McMURTRY J.A., CROFT B. 1997: Lifestyles of phytoseiid mites and their roles in biological control. Ann. Rev. Entomol. 42: 291-321.

NOMIKOU M., JANSSEN A., SCHRAAG R., SABELIS M.W. 2001: Phytoseiid predators as potential biological control agents for Bemisia tabaci. Exp. Appl. Acarol. 25: 271-291.

OVERMEER W.P.J., ZON van A.Q. 1981: A comparative study of the effect of some pesticides on three predacous mite species: Typhlodromus pyri, Amblyseius potentillae and A. bibens [Acarina: Phytoseiidae]. Entomophaga 26: 3-9.

PUCHALSKA E., PIOTROWSKA M. 2016: Side effects of acequinocyl on predatory mite Typhlodromus pyri Scheuten (Acari: Phytoseiidae). Commun. Biometr. Crop Sci. 11: 140-148.

RODRIGUES J.R., TORRES L.M. 2007: Field toxicity of four acaricides on the predatory mites Amblyseius andersoni (Chant) and Euseius stipulatus (Athias-Henriot) (Acari: Phytoseiidae) in apple orchard at Northwest of Portugal. Bulletin IOBC/WPRS 35: 143.

SALMAN S., AYDINLI F., AY R. 2015: Selection for resistance: Cross-resistance, inheritance, synergists and biochemical mechanisms of resistance to acequinocyl in Phytoseiulus persimilis A.H. (Acari: Phytoseiidae). Crop Prot. 67: 109-115.

SATO M., MIYATA T., KAWAI A., NAKANO O. 2000: Selection for resistance and susceptibility to methidathion and cross resistance in Amblyseius womersleyi Schicha (Acari: Phytoseidae). Appl. Etomol. Zool. 35: 393-399.

SOLOMON M.G., EASTERBROOK M.A., FITZGERALD J.D. 1993: Mite-management programs based on organophos- phate-resistant Typhlodromus pyri in UK apple orchards. Crop Prot. 12: 249-254.

STOJNIĆ B., MLADENOWIĆ K., MARIĆ I., MARCIĆ D. 2014: Species complexes of predatory mites and spider mites (Acari: Phytoseiidae, Tetranychidae) on cultivated and wild apple trees in Serbia. Int. J. Acarol. 7: 485-492.

SZABO A., PENZES B. 2013: A new method for the release of Amblyseius andersoni (Acari: Phytoseiidae) in young apple orchards. Eur. J. Entomol. 110: 477-482.

TIWARI S.N. 2013: Reduced Risk Pesticides: The Best Alternative to Ensure Food Safety without Compromising Environment Quality. In: Proceedings of the 27th Training on Managing Plant Microbe Interactions for the Management of Soil-borne Plant Pathogens. Centre of Advanced Faculty Training in Plant Pathology.

ZALOM F.G., IRIGARAY F.J.S.D.C. 2010: Integrating pesticides and biocontrol of mites in agricultural systems. In: Trends in Acarology: Proceedings of the 12th International Congress. Springer, Dordrecht.

Streszczenie: Selekcja Amblyseius andersoni (Chant) (Anactinotrichida: Phytoseiidae) $w$ kierunku odporności na acekwinocyl. Większość pestycydów stosowanych w zwalczaniu szkodników w sadach jest szkodliwa dla pożytecznych stawonogów. Wyselekcjonowanie drapieżców i parazytoidów odpornych na chemiczne środki ochrony roślin mogłoby przyczynić się do ich lepszego wykorzystania w uprawach, w których stosowanie pestycydów jest konieczne. Celem niniejszej pracy była selekcja linii drapieżnego roztocza Amblyseius andersoni odpornej na acekwinocyl - akarycyd należący do grupy inhibitorów transportu elektronów w kompleksie III mitochondrialnego łańcucha oddechowego. Jako dawkę selekcyjną zastosowano stężenie pestycydu powodujące śmiertelność 55-65\% zapłodnionych samic drapieżcy. U wyselekcjonowanej laboratoryjnie linii odnotowano dziewięciokrotny wzrost oporności na acekwinocyl po dwóch cyklach selekcyjnych i ponad 30-krotny wzrost po czterech cyklach. Wyselekcjonowana populacja 


$\begin{array}{ll}\begin{array}{l}\text { A. andersoni rozwinęła również umiarkowaną } \\ \text { opornośc krzyżową na fenpiroksymat. }\end{array} & \begin{array}{l}\text { Author's address: } \\ \text { Ewa Puchalska } \\ \text { (https://orcid.org/0000-0001-6032-3571) }\end{array} \\ \begin{array}{l}\text { Zakład Entomologii Stosowanej } \\ \text { selekcja, acekwinocyl, fenpiroksymat }\end{array} & \begin{array}{l}\text { Katedra Ochrony Roślin } \\ \text { Instytut Nauk Ogrodniczych }\end{array} \\ \text { MS received: } 10.12 .2019 & \begin{array}{l}\text { Szkoła Główna Gospodarstwa Wiejskiego } \\ \text { w Warszawie }\end{array} \\ \text { uS accepted: } 03.07 .2020 & \begin{array}{l}\text { ul. Nowoursynowska 159,02-776 Warszawa } \\ \text { e-mail: ewa_puchalska@sggw.edu.pl }\end{array}\end{array}$

